\title{
Eemian-Weichselian Pleniglacial fluvial deposits in southern Poland (an example of the Vistula River valley in Kraków)
}

\author{
Tadeusz SOKOŁOWSKI ${ }^{1, *}$, Agnieszka WACNIK², Barbara WORONKO ${ }^{3}$ and Jacek MADEJA ${ }^{4}$ \\ 1 AGH University of Science and Technology, Faculty of Geology, Geophysics and Environmental Protection, Al. A. Mickiewicza \\ 30, 30-059 Kraków, Poland \\ 2 Polish Academy of Sciences, Władysław Szafer Institute of Botany, Lubicz 46, 31-512 Kraków, Poland \\ 3 University of Warsaw, Faculty of Geography and Regional Studies, Krakowskie Przedmieście 30, 00-950 Warszawa, Poland \\ 4 Jagiellonian University, Institute of Botany, Lubicz 46, 31-512 Kraków, Poland
}

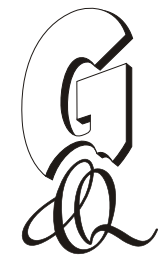

Sokołowski T., Wacnik A., Woronko B. and Madeja J. (2014) Eemian-Weichselian Pleniglacial fluvial deposits in southern Poland (an example of the Vistula River valley in Kraków) Geological Quarterly, 58 (1): 71-84, doi: 10.7306/gq.1138

\begin{abstract}
A fragment of the middle terrace in the Vistula River valley, nearby the railway station in Kraków, is formed by fluvial channel and overbank deposits of the Pradnik River, which bear a record of various environments affected by changing climatic conditions. The sedimentary succession includes two complexes that differ in lithofacies. The older complex comprises fining-upward deposits (channel sand and gravelly sand with medium- and large-scale trough cross-stratification) and, less frequently, sand with planar cross-stratification overlain by silt with intercalations of biogenic deposits of abandoned channels. Vegetation accompanying the deposition of biogenic layers was typical of boreal coniferous forests, dominated by Pinus sylvestris with a small admixture of Larix, Pinus cembra, Picea, Betula and Populus. Periodically, the landscape passed into open areas overgrown by woody tundra. The complex developed as a result of activity of a meandering river under conditions of a moderately cool climate. The younger complex includes the sand lithofacies with horizontal stratification and low-angle cross-stratification, overlain by alternating sands and silts. The topmost part is represented by sands with large- and medium-scale planar cross-stratification. Lack of biogenic deposits and considerable amount of frosted quartz grains in alluvial sediments indicate aeolian processes of greater intensity, periglacial conditions and evolution towards a braided or transitional river. Pollen successions, absolute dating and studies of structural and textural features of the sediment suggest that the time of its deposition may be estimated at a range between the close of the Eemian Interglacial and the Weichselian Middle Pleniglacial (OIS 5e-OIS 3).
\end{abstract}

Key words: Eemian-Weichselian, river deposits, sedimentology, pollen analysis, climate change, southern Poland.

\section{INTRODUCTION}

Kraków is located in the borderland of several large morphostructural units: the Sandomierz (Subcarpathian) Basin, Outer Carpathians and Kraków Plateau (Fig. 1). Most of the city is situated within the Sandomierz Basin, a depression filled mainly with Middle Miocene claystones and mudstones with less frequent sandy sediments. The latitudinally oriented Vistula valley extends over a large area of the basin. The Outer Carpathians, separated by an easily recognized morphological edge and composed of flysch sandstones and shales (Jurassic-Lower Miocene), rise to the south. The Kraków Plateau, an extensive area composed of hard Upper Jurassic limestones with flint concretions, slopes down in several steps from the

\footnotetext{
* Corresponding author, e-mail: tsokol@agh.edu.pl
}

Received: July 16, 2013; accepted: October 15, 2013; first published online: December 11, 2013 north. Eastwards, the plateau is covered mostly by Upper Cretaceous marls. All older rocks are locally overlain by Quaternary sediments of different origin and thickness.

Within the city, the major tributaries flow into the Vistula River: the left-bank Rudawa and Prądnik rivers, both draining the southern part of the Kraków Plateau and eroding the older Vistula River deposits, and the right-bank Wilga River, draining the Outer Carpathians. The lowest part of the valleys consists of a two-step floodplain. Upwards, in its northern part, the Vistula valley is marked by rising steps of terraces, sandy at the top, attaining the heights of $10-12$ and $15-20 \mathrm{~m}$ and divided into several patches by left-bank tributaries of the Vistula River. One of these patches is referred to as the Prądnik River fan and its origin was dated to the Saalian Glaciation (Tyczyńska, 1968), Weichselian Glaciation (Setmajer, 1973), and then to the Weichselian Upper Pleniglacial (Rutkowski, 1987).

In the previously drilled boreholes, alluvial deposits were encountered in the Vistula valley near the "Kraków Główny" railway station. Their maximum thickness was nearly $27 \mathrm{~m}$ (Fig. 2). A construction excavation located west of the railway platforms exposed the upper part of section, nearly $12 \mathrm{~m}$ in thickness, composed of fluvial detrital sediments (silts, sands, gravels) 


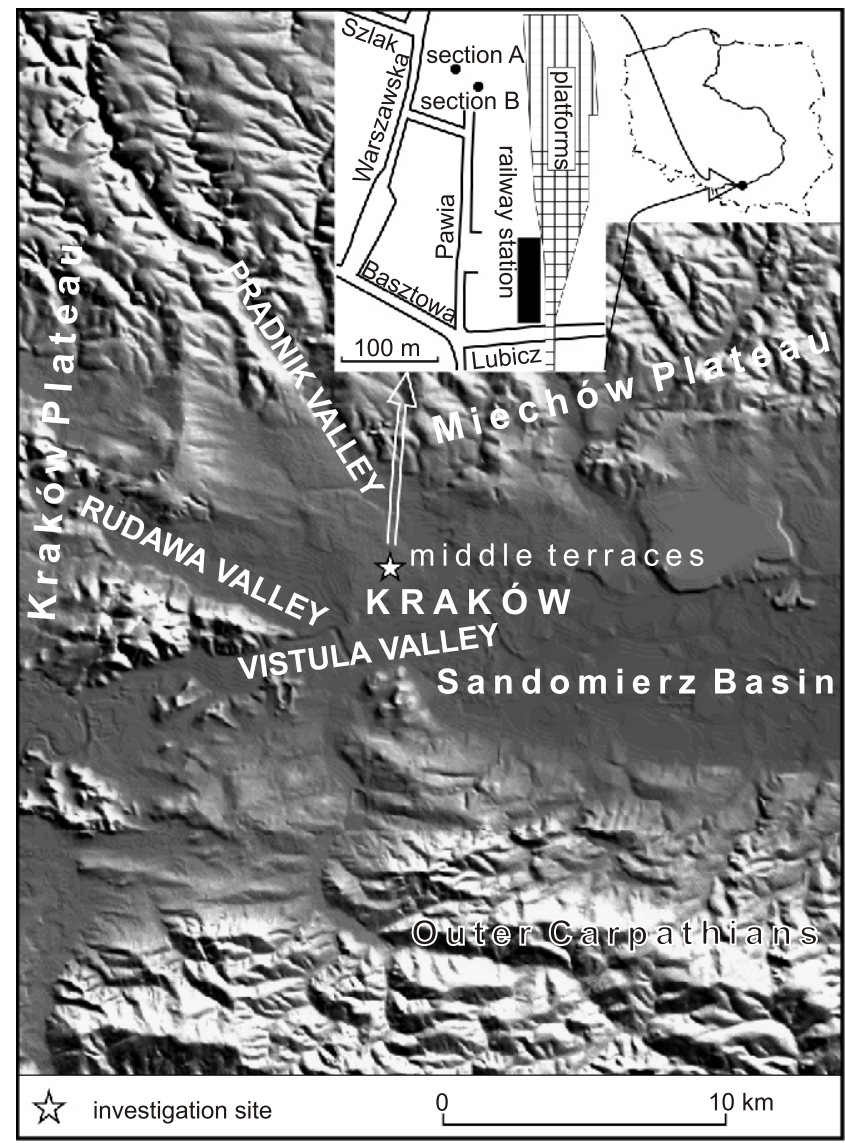

Fig.1. Location of the study area versus SRTM level 2 image

transported by the Pradnik to the Vistula valley, and biogenic deposits (peat; Fig. 2). Their top, within the excavation and its nearest surroundings, is elevated ca. $15-16 \mathrm{~m}$ above the present-day Vistula channel.

Presently, the Prądnik River is narrow, only locally exceeding $5 \mathrm{~m}$ in width, and flows in a bed straightened and largely channelized. The 18th and 19th century maps show a meandering channel pattern. The catchment covers an area of over $200 \mathrm{~km}^{2}$ and the mean annual flows slightly exceed $1 \mathrm{~m}^{3} / \mathrm{s}$ (Pociask-Karteczka, 1994).
The purpose of the study was to: (1) reconstruct the conditions of sediment deposition by the Prądnik in the Vistula valley, (2) reconstruct the climatic changes accompanying alluvial accumulation, and (3) identify the age of the sediments.

\section{METHODS}

The objectives of the study were achieved with the use of structural, textural, palynological and plant macroremain analyses and dating, applied for sediments exposed in the excavation in two sections. The investigations included vertical and lateral diversity of the sediments.

\section{SEDIMENTOLOGICAL ANALYSIS}

Description of sedimentary structures is based on codes proposed by Miall (1996), as modified by Zieliński (1995). Thickness intervals used to determine the scale of lithofacies were as follows: up to $6 \mathrm{~cm}$ - small-scale, $6-30 \mathrm{~cm}-$ medium-scale, and over $30 \mathrm{~cm}$ - large-scale (see Zieliński, 1998).

\section{GRAIN-SIZE ANALYSIS}

The sediment material for identification of textural features was taken only from sandy deposits, and subjected to dry grain-size analysis using a set of sieves for fractions between 2.0 and $0.063 \mathrm{~mm}$ in an interval of $0.5 \mathrm{phi}$. The results provided a basis to calculate the basic grain-size parameters $\left(M_{z}, \sigma_{1}\right.$ and $S k_{1}$ ), following Folk and Ward (1957), and to plot the cumulative curves on probability plots.

\section{ROUNDING AND FROSTING OF QUARTZ GRAINS}

Quartz grains of the $0.8-1.0 \mathrm{~mm}$ fraction from all samples were subjected to analyses of surface rounding and frosting following Cailleux (1942), as modified by Goździk (1980, 1995) and Mycielska-Dowgiałło and Woronko (1998). The analysis compiles the type of grain surface, indicating the environment of sediment transport or of in situ weathering, with the rounding degree, presented according to a 9 degree scale (Krumbein, 1941). Seven types of quartz grain surfaces, bearing a record of

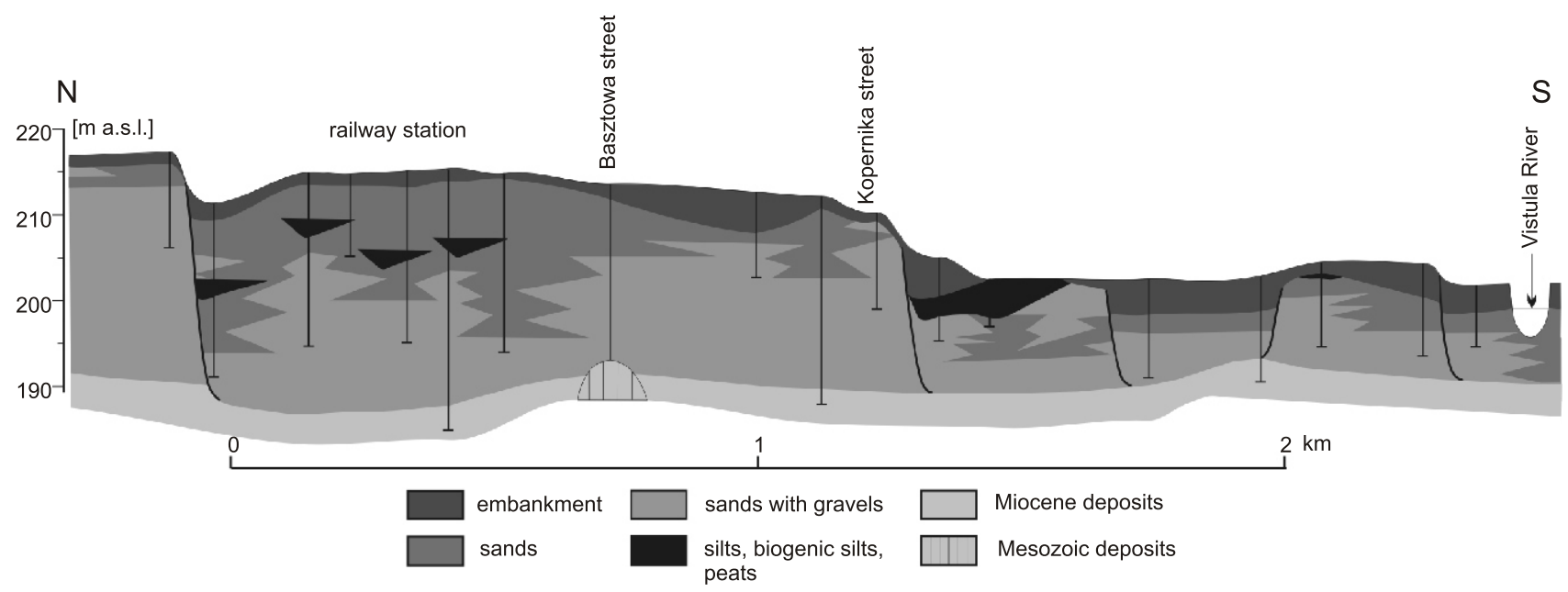

Fig. 2. Geological cross-section along part of the middle terrace of the Praqdnik River 
the last process that shaped their microrelief, were distinguished in the sandy fraction:

- RM - rounded and frosted grains (the rounding degree $0.7-0.9$ ), representing an aeolian environment. High level of surface rounding results from long-lasting abrasion (Mycielska-Dowgiałło, 2001);

- EM/RM - grains of frosted edges and corners, intermediate rounding degree $(0.3-0.6)$ and surface affected by abrasion for a relatively short time in an aeolian environment;

- EL - rounded and shiny grains (0.7-0.9), formed in aquatic environments (including fluvial and high-energy beach environments; Woronko and Ostrowska, 2009; Woronko et al., 2013);

- EM/EL - shiny grains of an intermediate rounding degree (0.3-0.6), representing aquatic environments;

- NU - completely fresh all grain surfaces, with no traces of chemical weathering or abrasion; 0.1-0.2, affected by damages in a glacial environment (e.g., Gomez and Small, 1983; Mahaney, 2002) or by weathering, e.g. frost action (Woronko and Hoch, 2011; Woronko, 2012a);
- C - broken, with at least a 30\% loss (Goździk, 1995) of the original grain surface. Only the broken surface is fresh and has sharp edges, not marked by traces of post-sedimentation processes;

- OTHER - grains of different rounding degrees, with a surface formed by strong chemical and/or mechanical weathering and not affected by abrasion.

For the same samples, percentage values of quartz grains were calculated, providing an indirect measurement of the duration of abrasion processes (Woronko, 2001; Mycielska-Dowgiałło and Woronko, 2004a, b).

\section{PALAEOBOTANICAL STUDIES}

Biogenic deposits were subjected to pollen and plant macroremain analyses. Samples for palynological examinations were taken in several-cm intervals from three sediment layers: C1 (9 samples), C2 (6 samples), and C3 (10 samples; Fig. 3). Single pilot samples were also collected from sands separating these layers. Chemical preparation of samples, with the volume of $1 \mathrm{~cm}^{3}$, followed the modified procedure of

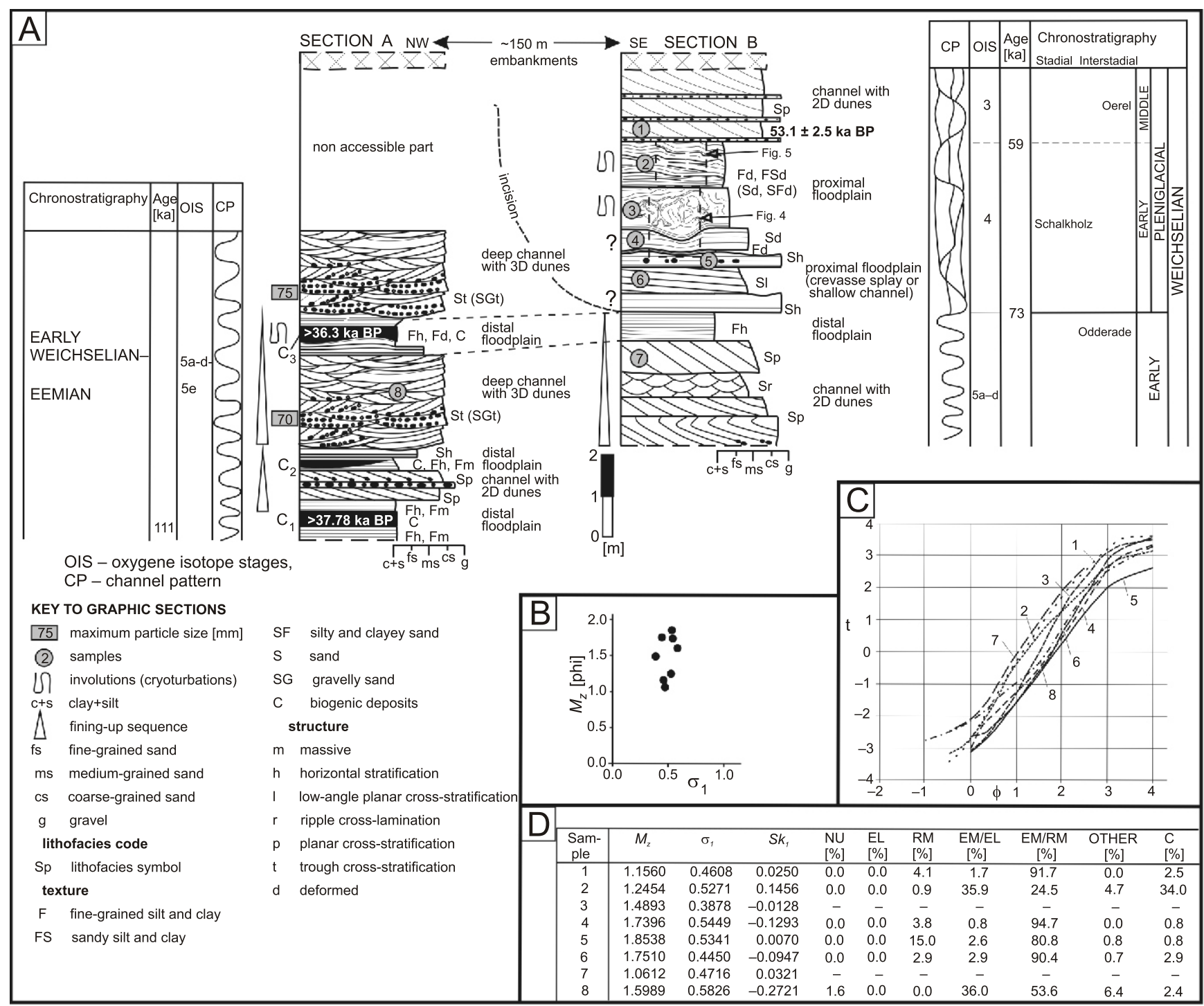

Fig. 3A - sedimentological sections related to chronostratigraphy, isotope stages and channel pattern; B - relationship between mean grain diameter $\left(M_{\mathbf{z}}\right)$ and standard deviation $\left(\sigma_{1}\right)$; C - granulation; D - rounding and frosting (chronostratigraphy, oxygen isotope stages, ages after Hammen et al., 1967; Martinson et al., 1987; Behre and Plicht, 1992; Dansgaard et al., 1993) 
Erdtman's acetolysis (Berglund and Ralska-Jasiewiczowa, 1986). In each sample, an average of 600 grains of trees and shrubs were identified. This figure included terrestrial, aquatic and swamp pollen as well as spores. Percentage values of sporomorphs were calculated with reference to the sum of pollen count for trees and shrubs (AP) and herbaceous plants (NAP), excluding local taxa. For swamp, aquatic and spore plants, the total sum was each time increased by the counts of remains of particular taxa. Morphological pollen types were determined with the use of keys of Moore et al. (1991) and Beug (2004), and the reference collection of the W. Szafer Institute of Botany, PAS, in Kraków. Percentage pollen diagrams were plotted with the POLPAL software for Windows. Distinction of Pollen Assemblage Zones (PAZs) was based on the ConSLink analysis (Walanus and Nalepka, 1999; Nalepka and Walanus, 2003).

The material for plant macroremain analysis was sampled in correlation with that for palynological studies. Samples, with the volume of ca. $200 \mathrm{ml}$, were macerated in $10 \% \mathrm{KOH}$ and sieved on sieves with the mesh diameter of $0.2 \mathrm{~mm}$. Remains of plants were selected for taxonomic identifications. Carpological studies and determination of wood and charcoal were performed by Zofia Tomczyńska.

\section{ABSOLUTE AGE DATING}

Radiocarbon and OSL absolute ages of biogenic and clastic sediments were determined at the GADAM Centre (Gliwice Absolute Dating Methods Centre, Silesian University of Technology, Poland). For conventional radiocarbon dating, two samples (ca. $100 \mathrm{~g}$ each) of strongly decomposed peat were taken from the middle of $\mathrm{C} 1$ and $\mathrm{C} 3$ layers. For OSL datings, one sample from the sand layer was collected (Fig. 3).

\section{RESEARCH RESULTS OF DEPOSITS}

The study covers one complete section (section B - Fig. 3) and the lower part of the second section (section A - Fig. 3). The sections are separated from each other by a large artificial slump.

\section{DETRITAL DEPOSITS}

Section A (Fig. 3A) is dominated by medium- and coarse-grained (nearly $50 \%$ of total thickness), well-sorted sand (Fig. 3D). The content of gravelly sand, silty sand and peat is subordinate.

The section is dominated by the sand and gravelly sand lithofacies with medium- and large-scale trough cross-stratification (St and SGt - Fig. 3A). Gravel grains are represented mostly by Jurassic limestones. A small proportion of Carpathian cobbles were noted in the lowermost part of the section. Sand with planar cross-stratification (Sp) and horizontal stratification $(\mathrm{Sh})$ is the secondary lithofacies.The following cycles have been identified: $\mathrm{St}(\mathrm{SGt}) \rightarrow \mathrm{Fh}(\mathrm{Fm}, \mathrm{C})$ or $\mathrm{Sp} \rightarrow \mathrm{Fh}(\mathrm{Fm}, \mathrm{C})$. The sand lithofacies attains ca. $2 \mathrm{~m}$ in thickness and is overlain by fine-grained deposits, usually forming sheet-like bodies of massive structure (Fm) or horizontal lamination (Fh). Each cycle includes peat $(C)$ in its upper part (Fig 3A).

Results of rounding and frosting analyses performed on quartz grains from section A show that lithofacies St and SGt (sample no. 8) are dominated by EM/RM grains, moderately rounded, which results from abrasion in an aeolian environ- ment. Their proportion is up to $53.6 \%$ (Fig. 3D). EM/EL grains, representing an aquatic environment, are abundant as well (36.0\%). "Other" $(6.4 \%)$ and broken grains $(2.4 \%)$ occur in minor amounts $(<10 \%)$. Fresh grains (NU) are also observed, in the frequency of $1.6 \%$ (Fig. 3D).

Section B (Fig. $3 A$ ) is dominated by medium-grained sand (Fig. 3B, D). In the lowermost and uppermost parts of section B, sand with large- and medium-scale planar cross-stratification $(\mathrm{Sp})$ is the main lithofacies. In the middle part the sand lithofacies, Sh and occasionally SI are present. The silt, sandy silt and silty sand lithofacies (Fd, FSd and SFd) are also found in relatively high proportions. Large-scale irregular involutions (load structures) occur in few silty and silty-sandy horizons, accounting for nearly $25 \%$ of section $B$. These large-scale structures, $>60 \mathrm{~cm}$ in amplitude, represent fold involutions of type 2 and 3, following Vandenberghe (2007; Fig. 4). The intensity of disturbances decreases upwards; the folds show a maximum amplitude slightly exceeding $30 \mathrm{~cm}$ (type 1 according to Vandenberghe, 2007; Fig. 5).

Results of grain-size analysis indicate that the sediments are well-sorted ( $\sigma_{1}$ from 0.38 to 0.58 ) and characterized by mean grain diameter $\left(M_{z}\right)$ varying between 1.85 and 1.06 phi and skewness $\left(S k_{1}\right)$ ranging from -0.27 to 0.14 (Fig. 3C, D). According to rounding and frosting analyses of quartz grain surface, following Cailleux (1942) with later modifications, section $B$ (samples nos. 1, 3-5) is noticeably dominated by grains processed in an aeolian environment. The sum of RM and EM/RM grains amounts to $93.3-98.5 \%$ (Fig. 3D), however generally (90.4-94.7\% of grains) only edges and corners are affected by aeolian processing. A bed comprising lithofacies Sh with single gravels is the only one including $15.0 \%$ of RM grains, typified by a very high level of rounding and completely frosted surface (sample no. 5; Fig. 3D).

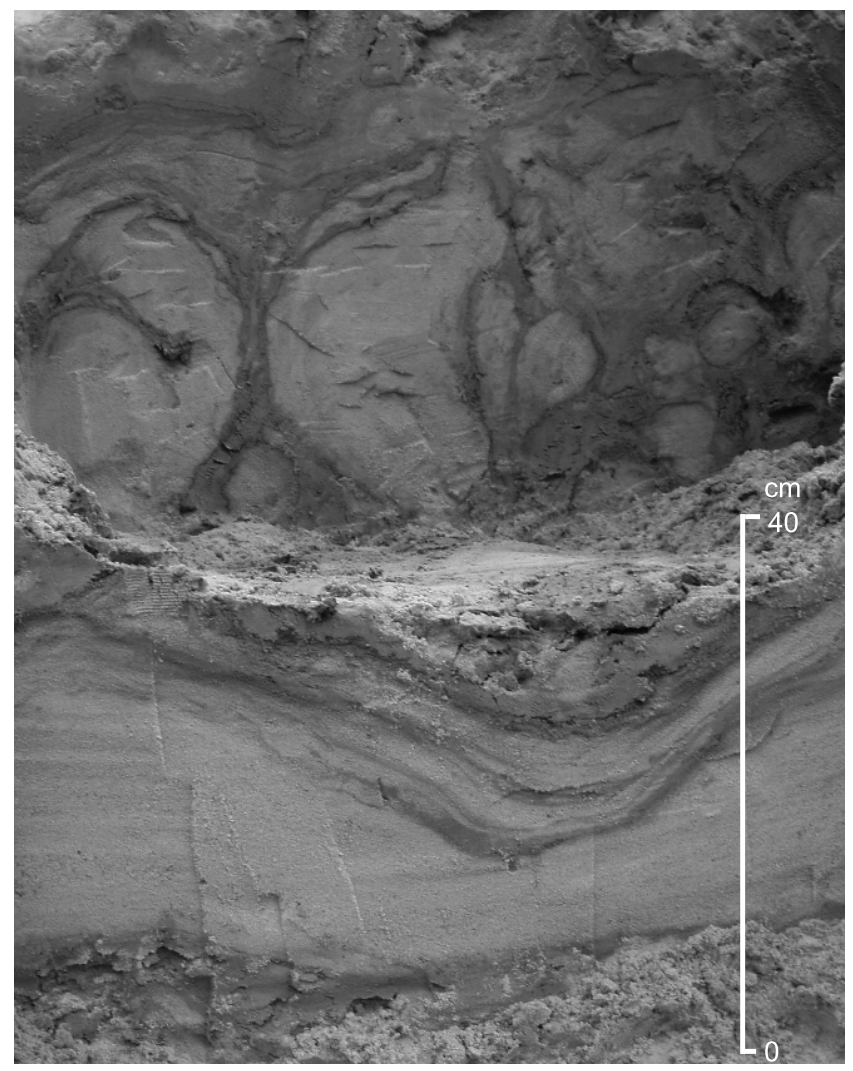

Fig. 4. Irregular cryoturbations in section B 


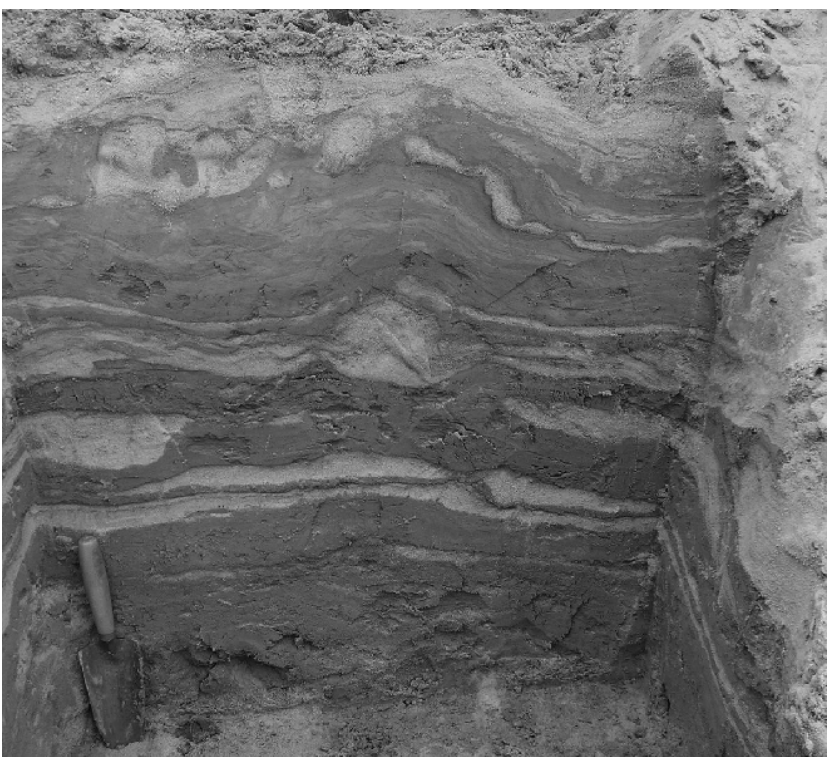

Fig. 5. Fold deformations in section B

Paddle is $30 \mathrm{~cm}$ high

Sample no. 2 is worth consideration as well because the grains from an aeolian environment (sum of RM and EM/RM) attain a frequency of $25.4 \%$. Grains with surfaces shaped mainly in an aquatic environment (EM/EL) and broken grains (C) are also found. The proportion of the latter is as much as $34 \%$, while in the other samples, it does not exceed $3 \%$ (Fig. 3D). They were formed as a result of destruction of grains representing both aeolian and aquatic environment. Such a variety of particle types indicates that they are in a secondary deposit, and the older sediments were derived from different sources (Woronko, 2012a).

\section{BIOGENIC DEPOSITS}

Biogenic deposits, represented by dark brown to almost black peat (layers $\mathrm{C} 1$ and $\mathrm{C} 2$ ) decomposed in $60-70 \%$, and dark brown sedge peat (layer C3) decomposed in 50-60\%, form three layers (C1, C2, C3 - Fig. 3A). They are interbedding the silt (Fh and Fm lithofacies) at the top part of fining-upward cycles. The topmost layer displayed slight involutions (small-scale folded structures - type 1 according to Vandenberghe, 2007).

\section{PALAEOBOTANICAL INVESTIGATIONS}

Pollen spectra of layer C1 (Figs. $3 \mathrm{~A}$ and 6) represent communities of boreal coniferous forests dominated by Scots pine (Pinus sylvestris) with a small admixture of spruce (Picea abies), larch (Larix), stone pine (Pinus cembra), poplar (Populus) and birch (Betula). As larch is recorded in high amounts, they most likely inhabited immediate surroundings of the site of sediment sampling. Ecological requirements of Larix as well as low pollen production and its limited dispersal (Jankovská and Pokorný, 2008) indicate local occurrence of patches of forest communities with low-density tree stands. Their ground layer was overgrown by Vaccinium, Lycopodium annotinum, Pteridium aquilinum, Dryopteris, and other ferns. Plants representing Poaceae and less frequently Artemisia, Cichorioideae, Ranunculus, Rubiaceae and Apiaceae were

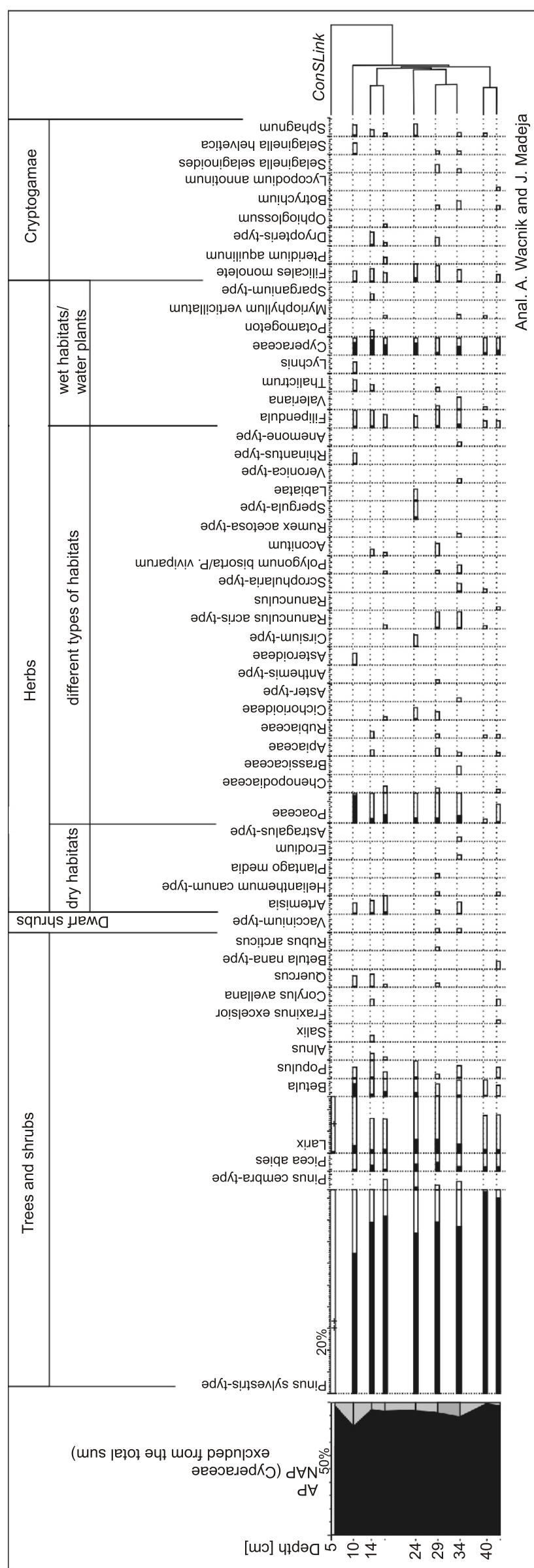




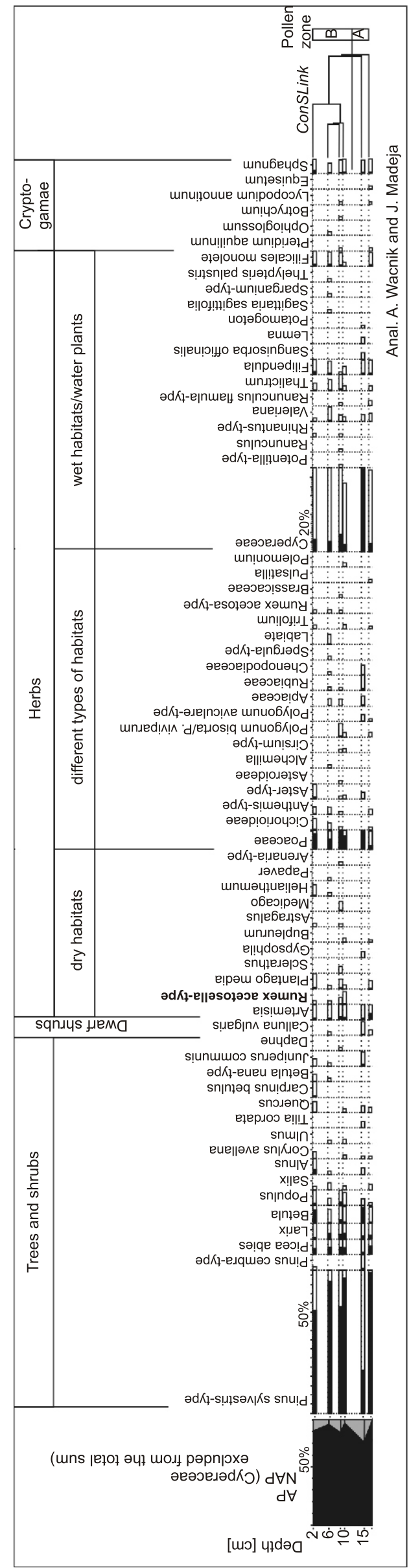

present in the ground layer and woodless areas. Relatively high amounts of Cyperaceae and Filipendula pollen, as well as the presence of Valeriana, Thalictrum, Lychnis, and Sphagnum, confirm the functioning of boggy, locally peaty habitats, occasionally including Betula nana. Humid grasslands were composed of Ophioglossum and Botrychium, while exposed grounds were covered by clubmosses (Selaginella selaginoides and S. helvetica). Periodically, waters of the basin remained open, allowing for the development of aquatic taxa: Potamogeton, Sparganium and Myriophyllum verticillatum.

Pollen analysis performed for the subsequent layer (C2 Figs. $3 \mathrm{~A}$ and 7 ) indicates a similar type of vegetation during the accumulation of organic sediments. The site was surrounded by boreal coniferous forests with Pinus sylvestris, admixture of Larix and single trees of Picea abies, Pinus cembra, Populus, Salix and Betula. In dry habitats, the shrub layer was overgrown by Daphne and Juniperus, while in wetlands, by Betula nana. Herbaceous vegetation was more abundant, possibly due to an increase in the surface of nearby woodless areas. Pollen of plants typical for dry habitats, such as Helianthemum, Scleranthus, Artemisia, Rumex acetosella-type and Plantago media, was found in minor amounts. Taxa requiring fresh and humid grounds were recorded more frequently and included mainly Poaceae, Rumex acetosa and Cichorioideae as well as plants representing Aster and Anthemis. One sample was marked by a very abundant occurrence of sedges (such as Cyperis fuscus and Scirpus sylvaticus, determined from macroremains), resulting from the increasing ground humidity. The presence of numerous Cyperaceae as well as Betula nana, Thalictrum flavum, Filipendula, Valeriana, Ranunculus flammula, Polemonium, Sanguisorba officinalis, Thelypteris palustris, Sphagnum, Lemna, Potamogeton and Sagittaria sagittifolia confirms the existence of boggy and peaty areas, periodically covered by open waters.

Layer C3 (Figs. 3A, 8 and 9) is marked by strongly decomposed sedge peat deposited in a shallow basin. The taxonomic composition of plant macroremains indicates the dominance of Cyperaceae, including genera such as Carex (C. dioica, C. stricta, C. limosa, C. leporina, C. arenaria, C. canescens, C. rostrata, C. pseudocyperus) and Scirpus (S. tabernaemontani, S. lacustris) were identified. Eleocharis palustris, Rynchospora alba, Poa sp. and Epilobium palustre (Fig. 9). The results of pollen analysis show a dual palynological record (Fig. 8). Spectra from the depth interval of $17-33 \mathrm{~cm}$ (zone C3a, Fig. 8) were very abundant in herbaceous plants, sedges and grasses. Vegetation of humid, boggy and aquatic habitats provides evidence for the development of a very shallow basin, with periodically opened water. Patches with Sphagnum, Drosera intermedia and Empetrum occurred locally. Shrubs of Betula nana appeared occasionally. Slightly drier areas were overgrown by Filipendula, Valeriana officinalis, Veronica serphyllifolia and Cirsium, while dry habitats, by Juniperus, Hippophaë rhamnoides, Calluna vulgaris, Artemisia, Chenopodiaceae, Achillea millefolium, Silene and Gypsophila. A numerous group of plants, like Poaceae, Apiaceae, Cichorioideae and Aster, was associated with various habitats.

The surroundings were occupied by pine forests with an admixture of spruce, stone pine and larch. The ground layer was overgrown by Juniperus. This zone is characterized by the highest proportion of birch. It inhabited both coniferous forests and the shore of the basin, where it was accompanied by single specimens of Salix, Cornus sanguinea, and possibly Alnus, Populus and Corylus avellana. The presence of Betula, Salix and Cornus sanguinea was confirmed also by the identification of their macroremains (Fig. 9). Infrequent pollen grains of Ulmus, Tilia cordata and Quercus were most likely carried in a 


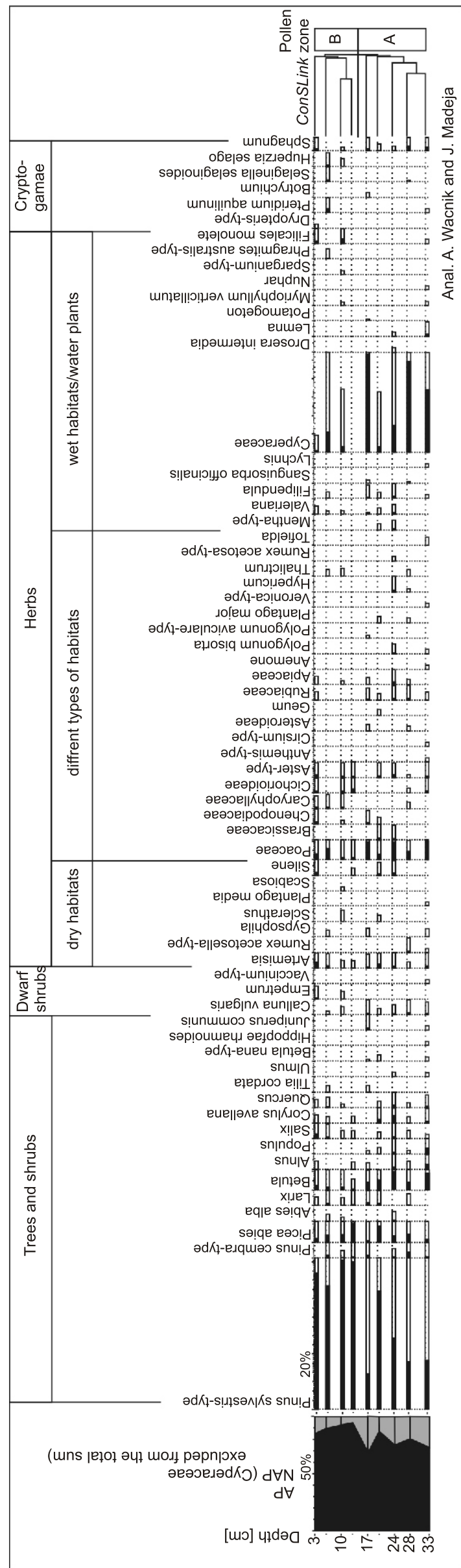

long-distance transport or redeposited. The presence of single particles of Quercus charcoal should be considered as an effect of redeposition, though in the lithology of this section, no mineral layers was observed, suggesting a higher input of older allochthonous matter. In this area, woody tundra, locally developed on grounds of high humidity, may have been the dominant plant formation.

Zone C3b (3-17 cm from the top, Fig. 8) bears a record of re-expansion of boreal coniferous forests, dominated by Scots pine with a small admixture of spruce and larch, which possibly resulted from a decrease in humidity. This observation was also confirmed by the presence of a $4 \mathrm{~cm}$ long Larix/Picea wood fragment at the top of the layer. Pinus sylvestris showed an increase in pollen frequency and was still accompanied by a high admixture of Picea. Larix occurred regularly, while Betula decreased its proportion. The values of herbaceous plants, particularly Cyperaceae and Poaceae, were strongly reduced, as confirmed by the results of macroremain analysis. No remains of aquatic plants were noticed, except for a single pollen grain of Myriophyllum verticillatum. Swamp plants were represented by Phragmites australis, Typha angustifolia and Carex stricta.

\section{INTERPRETATION OF DEPOSITIONAL ENVIRONMENTS}

The sediments examined are part of the terrace of the Pradnik River that drains the Kraków Upland in the north. It is evidenced by the petrographic composition of the gravels, dominated by Jurassic limestones. Only the admixture of Carpathian sandstones, found in the lowest part of the investigated outcrop, may indicate a slight influence of the Vistula or Rudawa rivers (cf. Rutkowski and Sokołowski, 1984).

Quartz grains in section B (except in sample no. 2) are very homogeneous in their type and are clearly dominated by grains affected by processing in an aeolian environment (RM and EM/RM types - over 95\%; Fig. 3A, D). It evidences the importance of aeolian processes occurring in the environment during accumulation of the series. In Kraków, similar amounts of this grain type were recorded in deposits of the lower terrace and originate in the Weichselian Late Pleniglacial (Sokołowski et al., 2008). The deposition of lithofacies Sh and SI overlying the silt sediments (section B - samples nos. 1-6) was preceded by slight incisions visible in some roof parts of these silt sediments. After the incisions, an abundant supply of aeolian sand to the river system may show its changes from meandering to sandy braided.

Nevertheless, it should be emphasized that traces of aeolian processes are easily recognized only at the edges and corners of grains, therefore they were either subject to abrasion for a relatively short time or the sediments were transported over a short distance (Mycielska-Dowgiałło, 1993; Woronko, 2001, 2012a). The slight increase in the proportion of aeolian grains, mainly of the RM type, observed upwards section $B$, is likely to evidence the synchronous occurrence of aeolian processes and accumulation of the examined deposits (Goździk, 2001; Woronko, 2012a). The cooling caused an increase in bedload and a tendency to braiding of the river. In the bottom of the valley, aggradation has occurred.

The deposits represent various fluvial subenvironments. Lithofacies St and SGt represent migration of 3D (lunate or linguoid) dunes and indicate deeper channel zones, whereas lithofacies Sp represents 2D (straight-crested) dunes or small transverse bars, being associated with straight and shallower inter-meander segments (McGowen and Garner, 1970; Jack- 


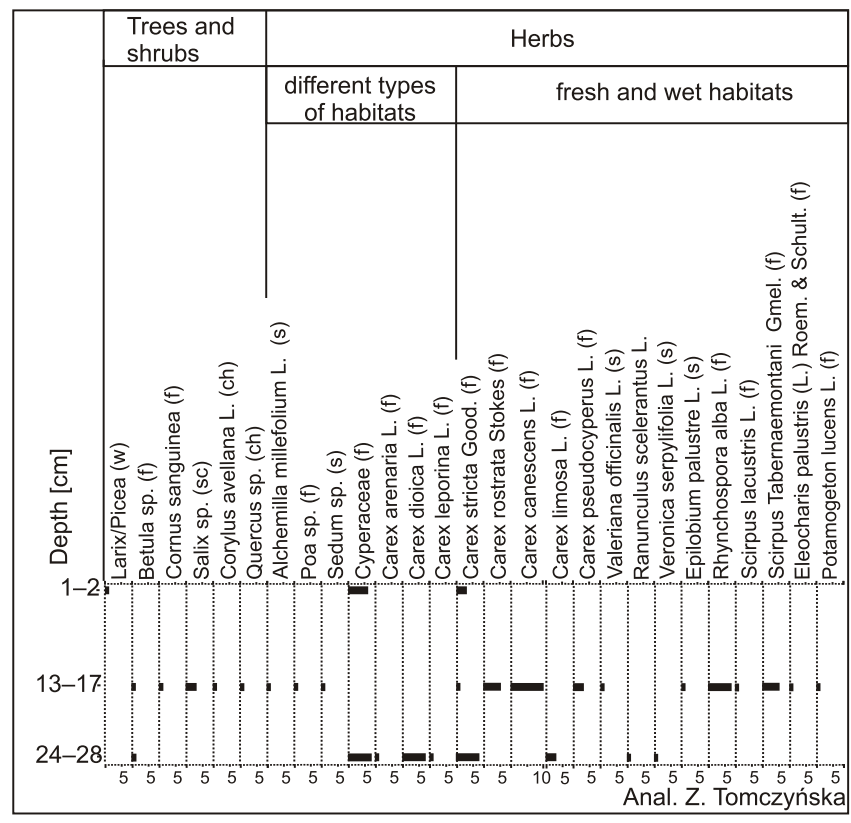

Fig. 9. Diagram of plant macrofossils from layer C3

ch - charcoal particles, $f-$ fruits, $s$ - seeds, $\mathrm{sc}$ - scales, $\mathrm{w}$ - wood fragment

son, 1976; Stewart, 1981; Bridge and Gordon, 1985). Lithofacies Sh and SI are likely to indicate the presence of very shallow channels with plane-bed morphology and low relief bars, however, may be also linked to crevasse splays (cf. Teisseyre, 1988; Gębica and Sokołowski, 2001). Fine-grained lithofacies (Fh and $\mathrm{Fm}$ ) represent the distal part of floodplain and, if peat occurs, represents abandoned channels. Deposits of the proximal floodplain are represented by sandy-silty alternations (lithofacies Fd, FSd, Sd, and SFd - Fig. 3A).

The sedimentation, particularly in the lower part, should be attributed to a meandering river system. This conclusion can be supported by following factors: (1) considerable frequency (about $50 \%$ ) of fine-grained lithofacies (Fh, Fm), biogenic deposits (peat) and sandy-silty alternations, (2) the occurrence of fining upward cycles $\mathrm{St}(\mathrm{SGt}) \rightarrow \mathrm{Fh}(\mathrm{Fm}, \mathrm{C})$ or $\mathrm{Sp} \rightarrow \mathrm{Fh}(\mathrm{Fm}, \mathrm{C})$ include the succession of: channel filling $\rightarrow$ channel abandoning, (3) the occurrence of peat (abandonment stage) indicate boreal coniferous forests and periodically woody tundra and (4) relatively inconsiderable content of aeolian grains.

In the middle and upper parts of the succession (section B), biogenic deposits are absent. A high proportion of aeolian grains and the presence of lithofacies Sh and SI (plane bed and low relief bars) may suggest passing into a transitional (threshold-type) river or into a sandy braided river.

\section{CHRONOSTRATIGRAPHY AND RIVER DEVELOPMENT IN RELATION TO CLIMATE AND ENVIRONMENTAL CHANGE}

\author{
EEMIAN AND WEICHSELIAN EARLY GLACIAL
}

ENVIRONMENTAL CONDITIONS

\begin{abstract}
The investigated sections (layers C1, C2 and C3b; Figs. 3, 6-9) bear a record of tree stands composed mainly of Scots pine with a small admixture of larch, stone pine, spruce, poplar and birch (Table 1). The reconstructed vegetation shows the dominance of boreal coniferous forest. Zone C3a is the only one marked by the development of woody tundra vegetation,
\end{abstract}

Chronostratigraphy and description of the pollen assemblage from the Kraków railway station

\begin{tabular}{|c|c|c|}
\hline $\begin{array}{c}\text { Chronostratigraphy } \\
\text { (Behre and Lade, 1986) }\end{array}$ & Layer & Results of pollen analysis \\
\hline \multirow{3}{*}{$\begin{array}{l}\text { Eemian-Weichselian } \\
\text { Early Glacial }\end{array}$} & C3 & $\begin{array}{l}71 \text { taxa were identified from pollen and spores. Percentage values of trees attain an average of ca. } 50 \% \\
\text { at the basal part and increase to ca. } 90 \% \text { in the top part. Pinus sylvestris is dominant, with a frequency } \\
\text { between } 20 \text { and } 81 \% \text { at the top. Continuous curve of Picea (up to } 10.6 \% \text { ). High proportion of Betula, } \\
\text { amounting to } 10 \% \text { at the base, shows a decreasing trend accompanied by falling values of Populus, } \\
\text { Corylus, Quercus, Alnus, and herbaceous plants. Nearly continuous presence of Pinus cembra-type } \\
\text { and Larix. Single pollen grains of shrubs: Juniperus, Betula nana-type and Hippophaë. Dwarf shrubs are } \\
\text { represented by a nearly continuous curve for Calluna and single records of Empetrum and Vaccinium. } \\
\text { Highest Cyperaceae values (up to } 53 \% \text {. are characteristic for the zone. Stable, several-percent high } \\
\text { frequency of Poaceae (up to } 10 \% \text { ). Constant occurrence of Artemisia (up to } 3.3 \% \text { ). Pollen of Aster-type, } \\
\text { Cichorioideae, Chenopodiaceae, Thalictrum, Apiaceae, Valeriana, Silene, and Gypsophila recorded } \\
\text { several times. Greater diversity of aquatic and swamp plants, with infrequent Lemna, Nuphar, } \\
\text { Sparganium-type, Potamogeton, Myriophyllum verticilatum-type, and Phragmites. Sphagnum and } \\
\text { Drosera intermedia found at the basal part. Spores of Pteridium aquilinum, Selaginella selaginoides, } \\
\text { Huperzia selago, Filicales monolete and Dryopteris-type mainly in top samples. }\end{array}$ \\
\hline & $\mathrm{C} 2$ & $\begin{array}{l}74 \text { taxa were identified. Spectra dominated by AP pollen, particularly of Pinus sylvestris (max. 75\%), } \\
\text { accompanied by a constant, several-percent high content of Picea (up to 4.6\%), Larix (up to 3.3\%) and } \\
\text { Betula (up to } 8.7 \% \text { ). Continuous curve of Populus. Taxa such as Salix, Alnus, Quercus, Pinus } \\
\text { cembra-type and Corylus avellana recorded several times. Shrubs represented by Juniperus, Betula } \\
\text { nana-type and Daphne. Within herbaceous plants, culmination of Cyperaceae (max. 44.3\%) at the } \\
\text { beginning of the zone. Frequency of Poaceae stable, attains max. 9.7\%. Continuous curves for } \\
\text { Artemisia, Filipendula and Valeriana and regularly recorded Plantago media-type, Rumex } \\
\text { acetosella-type, Aster-type, Anthemis-type, Thalictrum, Rubbiaceae and Apiaceae. Aquatic and swamp } \\
\text { plants recorded as single specimens (Lemna, Potamogeton, Sparganium-type, Sagittaria sagittifolia, } \\
\text { Thelypteris palustris). Spores of Filicales monolete and Sphagnum constantly present in spectra, } \\
\text { occasionally accompanied by Lycopodium annotinum, Ophioglossum and Pteridium. }\end{array}$ \\
\hline & C1 & $\begin{array}{l}61 \text { taxa were identified. Total dominance of AP pollen. Very high amounts of Pinus sylvestris (up to } \\
93 \% \text { ). Abundant Larix (up to 6.4\%). Constant, except for the top sample, occurrence of Picea (max. } \\
4.4 \% \text { ) and Betula (max. } 6 \% \text { ). Populus, Pinus cembra-type and Quercus recorded several times. Single } \\
\text { pollen grains of Betula nana-type and Rubus arcticus-type. Relatively infrequent appearance of NAP } \\
\text { taxa, with Poaceae, Cyperaceae and Filipendula as most important ones. Artemisia, Apiaceae, } \\
\text { Rubiaceae, Polygonum bistorta, Ranunculus acris-type, and Aconitum determined several times. } \\
\text { Pollen of aquatic plants found occasionally. Presence of spores of, i.a., Filicales monolete, Selaginella } \\
\text { selaginoides, Selaginella helvetica, Dryopteris-type, Ophioglossum and Sphagnum. }\end{array}$ \\
\hline
\end{tabular}


characterized by the coexistence of cold climate indicators, such as Pinus cembra, Larix, Betula nana, Rubus arcticus and Selaginella selaginoides, and infrequent remains of plants with higher temperature requirements, i.e. Myriophyllum verticillatum, Nuphar, Pteridium aquilinum, Sanguisorba officinalis and Drosera intermedia (Table 1). Its sediments were deposited in an increasingly humid habitat. Pollen succession from the Świnna Por site Broup or older in age Bińka and Grzybowski, 2002], revealed similarities in a general character of vegetation with a high frequency of Pinus sylvestris, Picea, Larix in local woods, but also differences: e.g. more open woodland communities with pine, higher representation of Alnus, regular presence of Picea omoricoides type and Bruckenthallia spiculifolia as well as Syringa, not found in our material.

The occurrence of pollen of both spruce and larch indicates a temperature of the coldest month ranging from -5 to $-2^{\circ} \mathrm{C}$. The presence of only Larix remains suggests mean temperatures of the warmest month likely to attain $+17^{\circ} \mathrm{C}$ (e.g., Dahl, 1998, Granoszewski, 2003; Kupryjanowicz, 2008), with a minimum mean July temperature of $14^{\circ} \mathrm{C}$, as evidenced by the appearance of pollen of Typha angustifolia Kolstrup, 1979) The occurrence of Betula nana allows for estimating the maximum temperature of the coldest month as not exceeding $0^{\circ} \mathrm{C}$, while the mean annual temperature determined for the taxon varies between -13.4 and $3.7^{\circ} \mathrm{C}$ (Tobolski, 1991; Granoszewski, 2003 Ballantyne et al., 2010). Selaginnella selaginoides, an Arctic-Alpine element, suggests temperatures of the warmest month falling below $17^{\circ} \mathrm{C}$ (Tobolski, 1991; Zarzycki et al., 2002). Following Mamakowa (1970), a range of $10-14^{\circ} \mathrm{C}$ should be accepted as the mean June temperature. It is specified to $13^{\circ} \mathrm{C}$ by the presence of Myriophyllum verticillatum.

\section{CHRONOSTRATIGRAPHY}

The Weichselian pollen successions so far described for Kraków and southern Poland are represented mostly by tundra and woody tundra vegetation, different from the one recorded in the examined section and generally representing the Weichselian Middle Pleniglacial particularly the Henge and Denekamp interstadials (e.g., Mamakowa and Środoń, 1977; Mamakowa and Rutkowski, 1989a, b).

The obtalned results, despite some differences, can be associated with the outcome of studies of plant associations and climatic reconstructions for the close of the Eemian and Early Weichselian interstadials in Eastern, Central and Western Europe (e.g., Behre and Lade, 1986; Bos et al., 2001; Velichko et al., 2005; Kühl et al., 2007; Brewer et al., 2008), including Poland (e.g., Mamakowa, 1989; Bińka and Grzybowski, 2002; Bińka and Nitychoruk, 2003; Granoszewski, 2003; Kupryjanowicz, 2008; Komar et al., 2009||Malkiewicz, 2010; Roman and Balwierz, 2010; Kuszell et al., 2012).

The sections known from Kraków and its immediate surroundings do not provide a continuous record of vegetation development in the Eemian Interglacial and the Early Weichselian. The examined biogenic deposits do not bear such a record either, therefore their chronostratigraphic position is arguable. The absolute age obtained from OSL for detrital sediments found in the upper part of the sections is $53.1 \pm 2.5 \mathrm{ka} \mathrm{BP}$ (Gd-1394). To some extent, this date is confirmed by the ${ }^{14} \mathrm{C}$ age of the lowest and uppermost layer of biogenic deposits, that appeared to be "infinite" (Gd-15733, >36.3 ka BP; Gd-12730, $>37.78 \mathrm{ka} \mathrm{BP}$ ). As there are no significant differences in the types of vegetation recorded in particular layers of biogenic deposits, they cannot be unequivocally correlated with any of the above-mentioned chronostratigraphic units. Therefore, it is also possible that all peat layers might have been deposited in the same period. However, the presence of three peat layers separated by detrital sediments may suggests that the layers, from the lowest one upwards, represent the close of the Eemian (OIS 5e) and the Brörup and Odderade interstadials, while the detrital sediments correspond to the Herning and Rederstall stadials (OIS 5a-d, Fig. 3). Although cryoturbations developed in the Early Glacial stadials in many places in Germany (e.g. Mol, 1997; Mol et al., 2000; Bos et al., 2001; Kasse et al., 2003), their absence in this site may be a result of a mild climate. The study area is, after all, located a few hundred kilometres south of the described places. However, the doubts regarding the age of the deposits due to the lack of a reference palaeobotanical site for comparison in this part of Poland require further studies.

RIVER DEVELOPMENT AND ENVIRONMENTAL CHANGES

The proposed interpretation of sediment age is supported by the texture of sand. During the Early Weichselian, aeolian activity was low in Western Europe (e.g. Kasse et al., 2003). n Poland, the formation of loess or dunes was not observed, and the low impact of aeolian processes is confirmed by the lack of RM grains (sample no. 8) and minor amounts of EM/RM grains (Fig. 3D). In Western Europe, the Early Weichselian was markedby the occurrence of periglacial phenomena evidenced by cryoturbations and ice-wedge casts (e.g., Bos et al., 2001 Kasse et al., 2003). Assuming that the small-amplitude folds observed in section A (type 1 according to Vandenberghe, 2007) represent cryoturbations and the lack of ice-wedges casts, it may be concluded that seasonal frost was episodic and relatively shallow in the study area.

During the Late Eemian and Weichselian Early Pleniglacial (OIS 5e-OIS 5a-d), the Prądnik River had a meandering channel pattern. Low-energy (meandering and/or anastomosing) channel patterns controlled by temperate climatic conditions in this period have been reported from many European regions (e.g., Mol, 1997; Huissteden et al., 2001; Zieliński and Goździk, 2001; Kasse et al., 2003; Zieliński, 2007; Sokołowski et al., 2009).

\section{WEICHSELIAN EARLY-MIDDLE PLENIGLACIAL}

ENVIRONMENTAL AND CLIMATIC CONDITIONS

Lack of biogenic deposits, high proportion of aeolian grains and the possible presence of involutions in the upper part of the deposits, may indicate climate cooling. A palynological record of vegetation near Kraków, from Polanów Samborzecki (Sandomierz Upland, ca. 140 km NE of Kraków), covering, i.a., vegetational changes until the Weichselian Early Glacial, includes open habitats with infrequent patches of pine-birch open forests. It is clearly dominated by NAP pollen evidencing mean temperature between -13 and $-16^{\circ} \mathrm{C}$ in the coldest month and between 16.5 and $17.5^{\circ} \mathrm{C}$ in the warmest month (Komar et al., 2009). Compared with earlier periods, this one was characterized by noticeably lower temperatures of the coldest months.

Climatic conditions may also be indicated by the occurrence of large-scale involutions. Although their origin is still under discussion (cf. Vandenberghe, 1988; Neuwerth et al., 2006; Loon, 2009), their presence together with textural features evidencing frost weathering suggests that they may have developed due to differential frost heave and periglacial loading. They are associated with permafrost and degradation of its top (Huijzer and Isarin, 1997; Kasse et al., 2007; Vandenberghe, 2007 Vliet-Lanoë, 2010). To be formed, they require mean annual air 
temperatures (MAAT) of $-8^{\circ} \mathrm{C}$ (up to $-6^{\circ} \mathrm{C}$ ), however, their development in sandy-silty alternations is likely to suggest a slightly higher MAAT of $-4^{\circ} \mathrm{C}$ (Vandenberghe and Pissart, 1993).

\section{CHRONOSTRATIGRAPHY}

Considering the dating of the uppermost segment of the deposits ( $\mathrm{Gd}-1394,53.1 \pm 2.5 \mathrm{ka} \mathrm{BP})$, it may be assumed that sediments forming this part of section B developed in the Weichselian Early Pleniglacial and in the initial phase of the Weichselian Middle Pleniglacial (OIS 4-OIS 3). During the former period (Shalkholz Stadial), entire Western and Central Europe was affected by strong cooling (e.g., Huijzer and Vandenberghe, 1998).

RIVER DEVELOPMENT AND ENVIRONMENTAL CHANGES

Environmental changes are definitely confirmed by features of deposits recorded in the upper part of section B. The Weichselian Early Pleniglacial (OIS 4) was marked by aeolian processes proceeding in the conditions of cold and dry climate in various regions of Poland (Dylik, 1969; Goździk, 1981; Buraczyński, 1994; Dzierżek and Stańczuk, 2006). Strong wind activity was also recorded in Western Europe (Vandenberghe, 1985; Huijzer and Vandenberghe, 1998) and resulted in the formation of fluvio-aeolian deposits (Vandenberghe and Huissteden, 1988; Mol et al., 1993).

The upper part of the alluvial deposits is typified by a noticeable increase in the amount of grains affected by aeolian processing. Grains transported by wind action may have been deposited directly in river channels (Huissteden et al., 2000; Mol et al., 2000; Kasse et al., 2003) or on floodplains (Kotarbiński et al., 2000; Huissteden et al., 2000; Mycielska-Dowgiałło and Woronko, 2001, 2004a, b; Woronko, 2012a). As humid sediments are highly cohesive, such grains could not be reincluded in aeolian transport. Conditions for the development of aeolian processes were particularly advantageous in the winter season (Isarin et al., 1997), mainly due to higher wind velocity than in the summer (Seppälä, 2004) and the release of sand grains from frozen ground in sublimation (McKenna and Neumann, 2004). In conditions of periglacial climate, aeolian material previously deposited in the valley bottom was incorporated into fluvial transport during short-lasting spring melts, remarkably increasing river flows (Kasse et al., 2007). Presently, similar events are observed in the zone of arctic or subarctic climate, e.g. in Alaska, in valley bottoms of snowmelt rivers (Lewkowicz and Young, 1991), Iceland (Moutney and Russell, 2004) and Canada (Good and Bryant, 1985). The results of grain-size analysis indicate that during their transport the deposits were not subjected to rapid deposition but to quite opposite processes of segregation and sorting, as evidenced by the very well-sorted saltation segment (Fig. 3C, D), including minor amounts of grains transported in solid suspension as well as dragged or rolled. However, comparison of the mean grain diameter $\left(M_{z}\right)$ and the degree of sorting $\left(\sigma_{1} ;\right.$ Fig. 3$)$ shows that the sediments represent a pattern typical of presently forming active parabolic dunes (Mycielska-Dowgiałło, 1995; MycielskaDowgiałło and Ludwikowska-Kędzia, 2011; Woronko, 2012a). It indicates that, in the fluvial environment, the sediments were transported over a short distance (Mycielska-Dowgiałło, 1993), in which their textural features, characteristic for the aeolian environment (i.e. grain size), could not be completely removed (Woronko et al., 2013).

In beds disturbed with involutions (Fig. 3 A, D, sample no. 2), sands have a very high content of broken grains (C), oc- currence of which may result from intense frost weathering in conditions of frequent freeze-thaw processes (e.g., Kowalkowski and Mycielska-Dowgiałło, 1985; Wright, 2000; Dietzel, 2005; Woronko and Hoch, 2011; Woronko, 2012b). Quartz is a more sensitive mineral to this type of weathering than, e.g., unweathered feldspar (Konishchev, 1982; Konishchev and Rogov, 1993; French and Guglielmin, 2000) due to the presence of gas-liquid inclusions (Rogov, 1982; Konishchev and Rogov, 1993; French and Guglielmin, 2000; Barczuk and Kozłowski, 2004; French, 2007; Woronko, 2012b). During freezing, solution found in the inclusions increases its volume, which results in the breaking of quartz grains. It should be also emphasized that the results of analyses, with later modifications, provide evidence for a change in the source of material in fluvial sediments, from only aeolian (sample no. 3) to originating from various environments. The occurrence of broken grains (C) shows an interruption in the floodplain deposition, lasting long enough to enable the formation of involutions and, first of all, production of broken grains. This event was likely to result from the progressive increase in climate aridity or fluvial down-cutting.

Structural features of deposits forming the upper segments of the section allow for various interpretations, however, to some extent, they suggest a change in the channel pattern towards a braided river, supported e.g., by open plant habitats dominant in the Weichselian Early Pleniglacial. High-energy braided channel patterns were recorded for this period at numerous sites in Europe (Mol et al., 2000). However, the Velyky Lukavets River in the Ukrainian Carpathians Foreland did not change its channel pattern in this period (Sokołowski and Stachowicz-Rybka, 2009). Textural features of the alluvial deposits indicate here that the Prądnik River changed the channel pattern from meandering to braided. The change of channel pattern was preceded by the incision of older deposits. Phases dessections dating for the end of the Early Weichselian and the beginning of the Weichselian Early Pleniglacial or the beginning Weichselian Middle Pleniglacial are recorded in different regions of Europe (e.g., Mol et al., 2000; Huissteden et al., 2001; Sokołowski et al., 2009). The vertical range of the incision is not precisely known, as the upper part of section $\mathrm{A}$ has not been examined.

\section{CONCLUSIONS}

In this region, the discussed site is the first one including alluvial deposits assigned to the Late Eemian-Weichselian Middle Pleniglacial (MIS 5e-MIS 3).

Fluvial sediments of the Prądnik in Kraków, exposed in a constructional excavation near the Kraków Główny railway station, bear a record of fluctuations in climate and climate-controlled plant associations. The pollen analysis of peat was supplemented by the results of identification of macroscopic plant remains. The Eemian-Early Weichselian (MIS 5e-MIS 5a-d) sedimentation proceeded in the environment of boreal coniferous forests dominated by common pine with a small admixture of Larix, Pinus cembra, Picea, Betula and Populus. The stands were of high density, however, the communities periodically passed into woody tundra most likely due to an increase in ground humidity. Among the three layers of biogenic deposits (C1, C2 and C3), separated by detrital sediments, the lowest one $(\mathrm{C} 1)$ was probably deposited in the Late Eemian, while the two others, in the Brörup and Odderade interstadials, respectively, representing the Early Weichselian. However, it cannot be excluded that all of them were deposited in the same warm 
period. The climatic condition during the sedimentation of peat layers were typified by a moderate climate with mean temperatures of the warmest month likely to attain even $+17^{\circ} \mathrm{C}$. Mean temperatures of the coldest month were presumably of several degrees below $0^{\circ} \mathrm{C}$.

Such conditions supported the existence of meandering channels, filled with fining-upward deposits of point-bars, with lithofacies St and SGt overlain by silt with biogenic deposits (abandoned phase). Straight, inter-meander channel segments included lithofacies Sp.

This sedimentary series is marked by an incision, dated at the close of the Early Weichselian. It is followed by a noticeable cooling of climate in the Weichselian Early Pleniglacial (Shalkholz Stadial), marked in the presence of abundant well-rounded and mat-surface aeolian grains in fluvial deposits. The content of aeolian grains increases upwards in the succession. Simultaneously, the channel pattern had changed. The Prądnik became a braided river. Therefore, the formation of this segment of the Prądnik River generally coincides with the development of European rivers and their response to environmental changes.

Acknowledgments. We thank M. Komar, W. Granoszewski, R. Stachowicz-Rybka, and two anonymous reviewers for their perceptive comments and suggestions. Thanks are due to $\mathrm{J}$. Olszak for his kind assistance in the field work. Financial support from the grant No. 11.11.140.175 is kindly acknowledged.

\section{REFERENCES}

Ballantyne A.P., Greenwood D.R., Sinninghe-Bamste J.S., Csank A.Z., Eberle J.J., Rybczynski N. (2010) Significantly warmer Arctic surface temperatures during the Pliocene indicated by multiple independent proxy. Geology, 38: 603-606.

Barczuk A., Kozłowski A. (2004) Fluid inclusions in quartz regeneration coatings in Buntsandstein from the northern margin of Świętokrzyskie Mts. Central Poland. Mineralogical Society of Poland Special Papers, 24: 91-95.

Behre K.-E., Lade U. (1986) Eine Folge von Eem und 4 Weichsel-Interstadialen in Oerel/Niedersachsen und inr Vegetationsablauf. Eiszeitalter und Gegenwart, 36: 11-36.

Behre K.-E., Plicht J., van der (1992) Towards an absolute chronology for the last glacial period in Europe: radiocarbon dates from Oerel, northern Germany. Vegetation History and Archaebotany, 1: 111-117

Berglund B.E., Ralska-Jasiewiczowa M. (1986) Pollen analysis and pollen diagrams. In: Handbook of Holocene Palaeoecology and Palaeohydrology (eds. E. Berglund and M. Ralska-Jasiewiczowa): 455-484. John Wiley and Sons Ltd., Chichester-Toronto.

Beug H.J. (2004) Leitfaden der Pollenbestimmung für Mitteleuropa und angrenzende Gebiete. Verlag Friedrich Pfeil, Münich.

Bińka K., Grzybowski K. (2002) Early Vistulian deposits at Świnna Poręba, Western Outer Carpathians (Southern Poland). Studia Quaternaria, 18: 11-16.

Bińka K., Nitychoruk J. (2003) The Late Saalian, Eemian and Early Vistulian pollen sequence at Dziewule, eastern Poland. Geological Quarterly, 47 (2): 155-168.

Bos J.A.A., Bohncke S.J.P., Kasse C., Vandenberghe J. (2001) Vegetation and climate during the Weichselian Early Glacial and Pleniglacial in the Niederlausitz, Eastern Germany macrofossil and pollen evidence. Journal of Quaternary Sciences, 16: 269-289.

Brewer S., Guiot J., Sánchez-Gońi M.F., Klotz S. (2008) The climate in Europe during the Eemian: a multi-method approach using pollen data. Quaternary Sciences Review, 27: 2303-2315.

Bridge J.S., Gordon E.A. (1985) Quantitative interpretation of ancient river systems in the Oeonta Fm. GSA Special Paper, 201: 163-181.

Buraczyński J. (1994) Changeability of eolian processes in Roztocze Upland and Sandomierz Basin during the Vistulian stage (in Polish with English summary). Annales Universitatis Mariae Curie-Skłodowska B, 49: 51-79.

Cailleux A. (1942) Les actiones éoliennes périglaciaires en Europe. Mémoires de la Société géologique de France, 41: 1-176.

Dahl E. (1998) Phytogeography of Northern Europe. Cambridge University Press, Cambridge.
Dansgaard W., Johnsen S.J., Clausen H.B., Dahl-Jensen D., Gundestrup N.S., Hammer C.U., Hvidberg C.S., Steffensen J.P., Sveinbjörndottir A.E., Jouzel J., Bond G. (1993) Evidence for general instability of past climate from a 250-kyr ice-core record. Nature, 364: 218-220.

Dietzel M. (2005) Impact of cyclic freezing on precipitation of silica in $\mathrm{Me}-\mathrm{SiO}_{2}-\mathrm{H}_{2} \mathrm{O}$ systems and geochemical implications for cryosoils and sediments. Chemical Geology, 216: 79-88.

Dylik J. (1969) L'action du vent pendant le dernier âge froid sur le territoire de la Pologne Centrale. Biuletyn Peryglacjalny, 20: 29-44.

Dzierżek J., Stańczuk D. (2006) Record and palaeogeographical implications of Pleistocene periglacial processes in the Drohiczyn Plateau, Podlasie Lowland (Eastern Poland). Geological Quarterly, 50 (2): 219-228.

Folk R.L., Ward W.C. (1957) Brazos river bar: a study in the significance of grain size parameters. Journal of Sedimentary Petrology, 21: 3-26.

French H.M. (2007) The Periglacial Environment. Third edition. John Wiley and Sons, Ltd., Chichester.

French H.M., Guglielmin M. (2000) Cryogenic weathering of granite, Northern Victoria Land, Antarctica. Permafrost and Periglacial Processes, 11: 305-314.

Gębica P., Sokołowski T. (2001) Sedimentological interpretation of crevasse splays formed during the extreme 1997 flood in the Upper Vistula river valley (south Poland). Annales Societatis Geologorum Poloniae, 71: 53-62.

Good T.R., Bryant I.D. (1985) Fluvio-aeolian sedimentation - an example from Banks Island, N.W.T., Canada. Geografiska Annaler, 67A: 33-46.

Goździk J. (1980) The role of micromorphologic analyses in investigations of the deposits in the Bełchatów open-cast mine (in Polish with English summary). Studia Regionalne, 4: 101-114.

Goździk J. (1981) Les changements de processus éoliens dans la Pologne Centrale au cours du Vistulien (Würm). Recherches géographiques à Strasbourg, 16-17: 115-120.

Goździk J. (1995) Selected methods of analysis of the sand grain shape for palaeogeographic and stratigraphic studies (in Polish with English summary). In: Researches of Quaternary sediments. Some methods and interpretation of the results (eds. E. Mycielska-Dowgiałło and J. Rutkowski): 115-132. Wydawnictwa Wydziału Geografii i Studiów Regionalnych Uniwersytetu Warszawskiego, Warszawa.

Goździk J. (2001) O zależności między pomiarami graniformametrycznymi a stopniem zaokrąglenia ziarn. In: Eolizacja osadów jako wskaźnik stratygraficzny czwartorzędu (ed. E. Mycielska-Dowgiałło): 21-31. Pracownia Sedymentologiczna, 
Wydział Geografii i Studiów Regionalnych, Uniwersytet Warszawski, Warszawa.

Granoszewski W. (2003) Late Pleistocene vegetation history and climatic changes at Horoszki Duże eastern Poland: a palaeobotanical study. Acta Palaeobotanica, Supplementum, $\mathbf{4}$ 3-95.

Gomez B., Small R.J. (1983). Genesis of englacial debris within the Lower Glacier de Tsidjiore Nouve, Valais, Switzerland, as revealed scanning electron microscope. Geografiska Annaler, 65A: 45-51.

Hammen T., van der, Maarleveld G.C., Vogel J.C., Zagwijn W. (1967) Stratigraphy, climatic succession and radiocarbon dating of the last glacial in the Netherlands. Geologie en Mijnbouw, $\mathbf{4 6}$ 79-95.

Huijzer A.S., Isarin R.F.B. (1997) The reconstruction of past climates using multi-proxy evidence; an example of the Weichselian Pleniglacial in northwestern and central Europe. Quaternary Sciences Review, 16: 513-533.

Huijzer A.S., Vandenberghe J. (1998) Climatic reconstruction of the Weichselian Pleniglacial in northwestern and central Europe. Journal of Quaternary Sciences, 13: 391-417.

Huissteden J., van, Vandenberghe J., Hammen T., van der, Laan W. (2000) Fluvial and aeolian interaction under permafrost conditions Weichselian Late Pleniglacial, Twente, eastern Netherlands. Catena, 40: 307-321.

Huissteden J., van, Gibbard P.L., Briant R.M. (2001) Periglacial fluvial systems in northwest Europe during marine isotope stages 4 and 3. Quaternary International, 79: 75-88.

Isarin R.F.B., Renssen H., Koster E.A. (1997) Surface wind climate during the Younger Dryas in Europe as inferred from aeolian records and model simulations. Palaeogeography, Palaeoclimatology, Palaeoecology, 134: 127-148.

Jackson R.G. (1976) Large-scale ripples of the lower Wabash River. Sedimentology, 23: 593-623.

Jankovská V., Pokorný P. (2008) Forest vegetation of the last full-glacial period in the Western Carpathians (Slovakia and Czech Republic). Preslia, 80: 307-324

Kasse C., Vandenberghe J., Huissteden J., van, Bohncke S.J.P., Bos J.A.A. (2003) Sensitivity of Weichselian fluvial systems to climate change (Nochten mine, eastern Germany). Quaternary Science Reviews, 22: 2141-2156.

Kasse C., Vanderberghe J., Corte F., de, Haute P., van den (2007) Late Weichselian fluvio-aeolian sands and coversands of the type locality Grubbenvorst (southern Netherlands): sedimentary environments, climate record and age. Journal of Quaternary Sciences, 22: 695-708.

Kolstrup E. (1979) Herbs as July temperature indicators for parts of the Pleniglacial and the Late-glacial in the Netherlands. Geologie en Mijnbouw, 59: 377-380.

Komar M., Łanczont M., Madeyska T. (2009) Spatial vegetation patterns based on palynological records in the loess area between the Dnieper and Odra Rivers during the last interglacial-glacial cycle. Quaternary International, 198: 152-172.

Konishchev V.N. (1982) Characteristic of cryogenic weathering in the permafrost zone of the European USSR. Arctic and Alpine Research, 14: 261-265.

Konishchev V.N., Rogov V.V. (1993) Investigations of cryogenic weathering in Europe and Northern Asia. Permafrost and Periglacial Processes, 4: 49-64.

Kotarbiński J., Mycielska-Dowgiałło E., Woronko B. (2000) Selected sedimentological features of deposits enabling their stratigraphical classification. Application to Galumin 1 borehole (central Poland) (in Polish with English summary). Przegląd Geologiczny, 48: 1030-1034.

Kowalkowski A., Mycielska-Dowgiałło E. (1985) Weathering of quartz grain in the liquefied horizon of permafrost solonchaka in the arid steppe zone, Central Mongolia. Catena, 12: 179-190.

Krumbein W.C. (1941) Measurement and geological significance of shape and roundness of sedimentary particles. Journal of Sedimentary Petrology, 11: 64-72.
KühI N., Litt T., Schölzel C., Hense A. (2007) Eemian and Early Weichselian temperature and precipitation variability in northern Germany. Quaternary Science Reviews, 26: 3311-3317.

Kupryjanowicz M. (2008) Vegetation and climate of the Eemian and Early Vistulian lakeland in northern Podlasie. Acta Palaeobotanica, 48: 3-130.

Kuszell T., Klaczak K., Bartczak E. (2012) New investigations into the Early Vistulian site at Białowice (Zielona Góra area, SW Poland). Geological Quarterly, 56 (1): 127-138.

Lewkowicz A.G., Young K.L. (1991) Observations of aeolian transport and niveoaeolian deposition at three lowland sites, Canadian Arctic Archipelago. Permafrost and Periglacial Processes, 2: $197-210$.

Loon A.J., van (2009) Soft-sediment deformation structures in siliciclastic sediments: an overview. Geologos, 15: 3-55.

Mahaney W.C. (2002). Atlas of Sand Grain Surface Textures and Applications. Oxford University Press.

Malkiewicz M. (2010) Early Vistulian vegetation history and climate change at Gutów (Wielkopolska Lowland) from pollen analysis. Geological Quarterly, 54 (3): 357-366.

Mamakowa K. (1970) Late-Glacial and Early Holocene vegetation from the territory of Kraków (Poland). Acta Palaeobotanica, 11: 3-12.

Mamakowa K. (1989) Late Middle Polish Glaciation, Eemian and Early Vistulian vegetation at Imbramowice near Wrocław and the pollen stratigraphy of this part of the Pleistocene in Poland. Acta Palaeobotanica, 29: 11-176.

Mamakowa K., Rutkowski J. (1989a) Wstępne wyniki badań paleobotanicznych profilu ze Ściejowic. In: Przewodnik 60 Zjazdu PTG, Kraków (ed. J. Rutkowski): 113-117. Państwowy Instytut Geologiczny, Akademia Górniczo-Hutnicza, Kraków.

Mamakowa K., Rutkowski J. (1989b) Wstępne wyniki badań litologicznych i paleobotanicznych profilu z Kryspinowa. In: Przewodnik 60 Zjazdu PTG, Kraków (ed. J. Rutkowski): 117-124. Państwowy Instytut Geologiczny, Akademia Górniczo-Hutnicza, Kraków.

Mamakowa K., Środon A. (1977) On the Pleniglacial flora from Nowa Huta and Quaternary deposits of the Vistula valley near Cracow (in Polish with English summary). Annales Societatis Geologorum Poloniae, 47: 485-511.

Martinson D.G., Pisias N.G., Hays J.D., Imbrie J., Moore T.C., Shackleton N.J. (1987) Age dating and the orbital theory of the ice ages: development of a high-resolution 0 to 300,000 -year chronostratigraphy. Quaternary Research, 27: 1-29.

McGowen J.H., Garner L.E. (1970) Physiographic features and stratification type of coarse grained point bars: modern and ancient examples. Sedimentology, 14: 77-111.

McKenna-Neuman C. (2004) Effects of temperature and humidity upon the transport of sedimentary particles by wind Sedimentology, 51: 1-17

Miall A.D. (1996) The Geology of Fluvial Deposits: Sedimentary Facies, Basin Analysis, and Petroleum Geology. Springer-Verlag, Berlin, Heidelberg, New York.

Mol J. (1997) Fluvial response to Weichselian climate changes in the Niederlausitz (Germany). Journal of Quaternary Science, 12: 43-60.

Mol J., Vandenberghe J., Kasse C., Stel H. (1993) Periglacial microjointing and faulting in Weichselian fluvio-aeolian deposits. Journal of Quaternary Science, 8: 15-30.

Mol J., Vandenberghe J., Kasse C. (2000) River response to variations of periglacial climate in mid-latitude Europe. Geomorphology, 33: 131-148.

Moore P.D., Webb J.A., Collinson M.E. (1991) Pollen Analysis. Blackwell Scientific Publications, Oxford.

Mountney N.P., Russell A.J. (2004) Sedimentology of cold-climate aeolian sandsheet deposits in the Alaska region of northeast Iceland. Sedimentary Geology, 166: 223-244.

Mycielska-Dowgiałło E. (1993) Estimates of Late Glacial and Holocene aeolian activity in Belgium, Poland and Sweden. Boreas, 22: $165-170$. 
Mycielska-Dowgiałło E. (1995) Selected textural features of deposits and their interpretation value (in Polish with English summary). In: Researches of Quaternary sediments. Some methods and interpretation of the results (eds. E. Mycielska-Dowgiałło and J. Rutkowski): 29-104. Wydawnictwa Wydziału Geografii i Studiów Regionalnych Uniwersytetu Warszawskiego, Warszawa.

Mycielska-Dowgiałło E. (2001) Teksturalne cechy osadów wskazujące na stopień ich eolizacji i pozycję stratygraficzną. In: Eolizacja osadów jako wskaźnik stratygraficzny czwartorzędu (ed. E. Mycielska-Dowgiałło): 9-17. Pracownia Sedymentologiczna, Wydział Geografii i Studiów Regionalnych, Uniwersytet Warszawski, Warszawa.

Mycielska-Dowgiałło E., Ludwikowska-Kędzia M. (2011) Alternative interpretations of grain-size data from Quaternary deposits. Geologos, 17: 189-203.

Mycielska-Dowgiałło E., Woronko B. (1998) Rounding and frosting analysis of quarto grains of sand fraction, and its interpretative value (in Polish with English summary). Przegląd Geologiczny, 46: 1275-1281.

Mycielska-Dowgiałło E., Woronko B. (2001) Wybrane cechy sedymentologiczne osadów ułatwiające ich podział stratygraficzny, na przykładzie otworów Galumin 1, Kozły K-1, Niksowizna i Olszewo Węgorzewskie. In: Eolizacja osadów jako wskaźnik stratygraficzny czwartorzędu (ed. E. MycielskaDowgiałło): 43-58. Pracownia Sedymentologiczna, Wydzia Geografii i Studiów Regionalnych, Uniwersytet Warszawski, Warszawa.

Mycielska-Dowgiałło E., Woronko B. (2004a) The degree of aeolization of Quaternary deposits in Poland as a tool for stratigraphic interpretation. Sedimentary Geology, 168: 149-163.

Mycielska-Dowgiałło E., Woronko B. (2004b) Zagadnienie seril interglacjalnych w świetle cech teksturalnych osadów. In: Geneza, Litologia i Stratygrafia Utworów Czwartorzedowych (ed. A. Kostrzewski): 313-328. Wydawnictwa Naukowe Uniwersytetu Adama Mickiewicza, Poznań

Nalepka D., Walanus A. (2003) Data processing in pollen analysis. Acta Palaeobotanica, 43: 125-134.

Neuwerth R., Suter F., Guzman C.A., Gorin G.E. (2006) Soft-sediment deformation in a tectonically active area: the Plio-Pleistocene Zarzal Formation in the Cauca Valley (Western Colombia). Sedimentary Geology, 186: 67-88.

Pociask-Karteczka J. (1994) Changes of water conditions at the Cracow area (in Polish with English summary). Zeszyty Naukowe Uniwersytetu Jagiellońskiego, 1144: 1-39.

Rogov V.V. (1982) Quartz particle surfaces as evidence of cryogenic weathering. Problems of Cryolithology, 10: 68-75.

Roman M., Balwierz Z. (2010) Eemian and Vistulian pollen sequence at Kubłowo (Central Poland): implications for the limit of the Last Glacial Maximum. Geological Quarterly, 54 (1): 55-68.

Rutkowski J. (1987) Vistula river valley in the Cracow Gate during the Holocene. Polish Academy of Sciences, Institute of Geography and Spatial Organization, Geographical Studies, Special Issue 4: $31-50$

Rutkowski J., Sokołowski T. (1983) Preliminary petrographic study of Quaternary fluvial gravels of the Cracow region - southern Poland. (in Polish with English summary). Studia Geomorphologica Carpatho-Balcanica, 16: 99-108.

Seppälä M. (2004) Wind as geomorphic agent in cold climates Cambridge University Press, Cambridge.

Setmajer J. (1973) Main features of geological structure and primary topography of the Cracow area and the neighbouring (Subcarpathian region) (in Polish with English summary). Acta Archaeologica Carpathica, 13: 139-151.

Sokołowski T., Stachowicz-Rybka R. (2009) Chronostratigraphy and changes of environment of Late Pleistocene and Holocene at Starunia palaeontological site and vicinity (Carpathian region, Ukraine). Annales Societatis Geologorum Poloniae, 79: 315-331.

Sokołowski T., Wacnik A., Wardas M., Pawlikowski M., Pazdur A., Madeja J., Woronko B., Madej P. (2008) Changes of natural environment in Kraków downtown - its chronology and directions. Case geoarcheological studies of Krupnicza Street site. Geochronometria, 31: 7-19.

Sokołowski T., Stachowicz-Rybka R., Woronko B. (2009) Upper Pleistocene and Holocene deposits around Starunia palaeontological site (Carpathian region, Ukraine). Annales Societatis Geologorum Poloniae, 79: 255-278.

Stewart D.J. (1981) A meander-belt sandstone of the Lower Cretaceous of South England. Sedimentology, 28: 1-20

Teisseyre A.K. (1988) Recent overbank deposits of the Sudetic valleys, SW Poland. P. III: Subaerially and subaqueously deposited overbank sediments in the light of field experiment 1977-79. Geologia Sudetica, 23: 1-64.

Tobolski K. (1991) Biostratigraphy and palaeoecology of the Eemian interglacial and the Vistulian glaciation of the Konin region (in Polish with English summary). In: Przemiany środowiska geograficznego obszaru Konin-Turek (ed. W. Stankowski): 45-87. Wydawnictwa Naukowe Uniwersytetu Adama Mickiewicza, Poznań.

Tyczyńska M. (1968) Geomorphological evolution of the city of Cracow (in Polish with English summary). Zeszyty Naukowe Uniwersytetu Jagiellońskiego, 173: 1-68.

Vandenberghe J. (1985) Palaeoenvironment and stratigraphy during the Last Glacial in the Belgian-Dutch region. Quaternary Research, 24: 23-38.

Vandenberghe J. (1988) Cryoturbations. In: Advances in Periglacial Geomorphology (ed. M.J. Clark): 179-198. John Wiley and Sons Ltd, Chichester.

Vandenberghe J. (2007) Cryoturbation structures. In: Encyclopedia of Quaternary Science (ed. S.A. Ellias): 2147-2153. Elsevier B.V.

Vandenberghe J., Huissteden J., van (1988) Fluvio-aeolian interaction in a region of continuous permafrost. In: 5 th International Conference on Permafrost, Proceedings: 876-881. Tapir Publishing, Trondheim.

Vandenberghe J., Pissart A. (1993) Permafrost changes in Europe during the last glacial. Permafrost and Periglacial Processes, 4: 121-135.

Velichko A.A., Novenko E.Y., Pisareva V.V., Zelikson E.M., Boettger T., Junge F. (2005) Vegetation and climate changes during the Eemian interglacial in Central and Eastern Europe: comparative analysis of pollen data. Boreas, 34: 207-219.

Vliet-Lanoë B., van (2010) Frost action. In: Interpretation of micromorphological features of soils and regoliths (eds. G. Stoops, V. Marcellino and F. Mees): 81-108. Elsevier, London.

Walanus A., Nalepka D. (1999) POLPAL programs for counting pollen grains, diagrams plotting and numerical analysis. Acta Palaeobotanica, Supplementum, 2: 659-661.

Woronko B. (2001) Znaczenie analizy obtoczenia i zmatowienia powierzchni ziarn kwarcowych frakcji piaszczystej W interpretacji genetycznej osadów czwartorzędowych. In: Eolizacja osadów jako wskaźnik stratygraficzny czwartorzędu (ed. E. Mycielska-Dowgiałło): 33-38. Pracownia Sedymentologiczna, Wydział Geografii i Studiów Regionalnych, Uniwersytet Warszawski, Warszawa.

Woronko B. (2012a) Records of aeolian processes in the Pleistocene sandy sediments in selected areas of central and north-eastern Poland (in Polish with English summary). Uniwersytet Warszawski, Wydział Geografii i Studiów Regionalnych, Warszawa.

Woronko B. (2012b) Micromorphology of quartz grains as a tool in the reconstruction of periglacial environment. Contemporary Issues in Polish Geography: 111-131. Bogucki, Wydawnictwo Naukowe, Poznań.

Woronko B., Hoch M. (2011) The development of frost-weathering microstructures on sand-sized quartz grains: examples from Poland and Mongolia. Permafrost and Periglacial Processes, 22 214-227.

Woronko B., Ostrowska M. (2009) The influence of a fluvial environment on the micromorphology of quartz grain surfaces - discussion (in Polish with English summary). In: Geneza, litologia i stratygrafia utworów czwartorzędowych (ed. A. Kostrzewski and 
R. Paluszkiewicz): 605-622. Wydawnictwa Naukowe Uniwersytetu Adama Mickiewicza, Poznań.

Woronko B., Giriat D., Kosiak A. (2013). Micromorphology of quartz grains as a tool to recognise fluvial deposits on an examples of field and experimental study. In: Conference Programme and Abstract Volume (eds. D.R. Parsons, P.J. Ashworth, J.L. Best and C.J. Simpson): 256. 10th International Conference on Fluvial Sedimentology, University of Leeds, UK, July 14-19, 2013.

Wright J. S. (2000) The spalling of overgrowths during experimental freeze-thaw of quartz sandstone as mechanism of quartz silt production. Micron, 31: 631-638.

Zarzycki K., Trzcińska-Tacik H., Różański W., Szeląg Z., Wołek J., Korzeniak U. (2002) Ecological indicator values of vascula plants of Poland. In: Biodiversity of Poland 2 (ed. Z. Mirek). Władysław Szafer Institute of Botany, Polish Academy of Sciences, Kraków.

Zieliński T. (1995) Lithofacies and genetic codes: construction and application (in Polish with English summary). In: Researches of
Quaternary sediments. Some methods and interpretation of the results (eds. E. Mycielska-Dowgiałło and J. Rutkowski): 220-235. Wydawnictwa Wydziału Geografii i Studiów Regionalnych Uniwersytetu Warszawskiego, Warszawa.

Zieliński T. (1998) Lithofacial identification of alluvial sediments (in Polish with English summary). In: Sedimentological and postsedimentological structures in Quaternary sediments and their value for interpretation, (ed. E. Mycielska-Dowgiałło): 195-257. Wydawnictwa Wydziału Geografii i Studiów Regionalnych Uniwersytetu Warszawskiego, Warszawa.

Zieliński T. (2007) The Pleistocene climate-controlled fluvial sedimentary record in the Bełchatów mine (central Poland). Sedimentary Geology, 193: 203-209.

Zieliński T., Goździk J. (2001) Palaeoenvironmental interpretation of a Pleistocene alluvial succession in central Poland: sedimentary facies analysis as a tool for palaeoclimatic inferences. Boreas, 30: 240-253. 